\title{
MATIZES DA CULTURA JOVEM: IMAGENS E IMAGINÁRIOS EM TORNO DO FESTIVAL DE CINEMA AMADOR JB/MESBLA
}

Hues of youth culture: images around the Amateur Film Festival JB/Mesbla

Tonos de la cultura juvenil: imágenes e imaginarios en torno al Festival de Cine Amateur JB/Mesbla

LILA FOSTER $^{\mathrm{I}^{*}}$

https://doi.org/10.1590/S2178-149420210103

'Universidade de Brasília - Brasília (DF), Brasil.

*Pós-Doutoranda no Programa de Pós-Graduação em Comunicação da Universidade de Brasília, com projeto de pesquisa dedicado ao Festival de Cinema Amador do Jornal do Brasil (1965-1970) (lilafoster@gmail.com).

(D) https://orcid.org/0000-0002-5778-2969

Artigo recebido em 01 setembro de 2020 e aprovado para publicação em 11 novembro de 2020. 


\title{
RESUMO
}

Em 1965, o Jornal do Brasil organizou a primeira edição do Festival de Cinema Amador, no Rio de Janeiro, Brasil. Entre 1965 e 1970, o festival agregou a produção de cineastas em início de carreira e diletantes ao redor do país. Fruto de intensas transformações ocorridas no cenário cultural carioca, imprensa e cinema tiveram centralidade na formação da cultura jovem, imagens e imaginários que compõem a cultura visual da época. No presente artigo mapearemos as forças que atuaram na criação desse certame voltado para os jovens talentos do cinema brasileiro, o imaginário em torno da cultura jovem da época e a análise de filmes concorrentes.

PALAVRAS-CHAVE: Cinema Brasileiro; Cinema Amador; Jornal do Brasil; Cultura Jovem.

\begin{abstract}
In 1965, Jornal do Brasil organized the first edition of the Amateur Film Festival, in Rio de Janeiro, Brazil. Between 1965 and 1970, the festival screened the first films of filmmakers that would lead a carrer in cinema and works from dilettantes around the country. As a result of intense cultural transformations that have taken place in the cultural scene in Rio, press and cinema had a central role in the formation of youth culture, imagery that make up the visual culture of the time. We will map the forces that acted in the creation of this event, aimed at the young talents of Brazilian cinema, the imagery surrounding youth culture, and the analysis of competing films.
\end{abstract}

KEYWORDS: Brazilian Cinema; Amateur cinema; Jornal do Brasil; Youth Culture.

\section{RESUMEN}

En 1965, Jornal do Brasil organizó la primera edición del Festival de Cine Amateur, en Rio de Janeiro, Brazil. Entre 1965 y 1970, el festival sumó la producción de cineastas en el inicio de sus carreras y diletantes de todo el país. Como resultado de las intensas transformaciones que se han producido en el escenario cultural de Río, la prensa y el cine tendrán un papel central en la formación de la cultura juvenil, las imágenes y el imaginario que conforman la cultura visual de la época. En este artículo mapearemos las fuerzas que actuaron en la creación de este evento, dirigido a los jóvenes talentos del cine brasileño, el imaginario en torno a la cultura juvenil de la época y el análisis de películas en competencia.

PALABRAS ClAVE: Cine Brasileño; Cine Amateur; Jornal do Brasil; Cultura Juvenil. 


\section{INTRODUÇÃO}

$\mathrm{E}$ m dezembro de 1964, o Jornal do Brasil anunciou a organização de diversas atividades em torno da comemoração do IV Centenário da Cidade do Rio de Janeiro. Entre os eventos divulgados nas páginas do Caderno B estava o festival de cinema amador, a ser realizado em meados de 1965, em conjunto com uma programação que incluía festival de música, concurso de caricaturas e uma competição de pesca. 0 cinema amador complementava uma iniciativa de aproximação do jornal com os seus leitores, que abrangia um grande arco de atividades e hobbies, com o objetivo também de enaltecer a vocação cultural da cidade do Rio de Janeiro.

As atenções do jornal voltadas às comemorações do IV Centenário e ao cinema tinham como pano de fundo dois processos de transformação no cenário cultural carioca. 0 primeiro foi a perda de status da cidade para a recém-inaugurada Brasília e a tentativa, por parte do governo do então estado da Guanabara, de ressaltar o valor cultural da cidade. Os incentivos a instituições culturais e a criação de novos espaços, como o Museu da Imagem e do Som inaugurado em 1965, tinham como estratégia a conformação de uma memória coletiva sobre a cidade do Rio de Janeiro e o seu estabelecimento como capital cultural do país, com suas características locais, mas também seu caráter cosmopolita (Lima, 2006).

Nesse contexto, o segundo movimento diz respeito às transformações na estrutura do Jornal do Brasil, modernização que começa no final dos anos 1950 com a reforma gráfica encabeçada pelo artista Amílcar de Castro e a publicação do "Suplemento Dominical". Dá-se, então, início ao processo que buscava uma nova inserção do periódico no debate cultural da cidade. Em 1960, o jornal passa o publicar o Caderno B, voltado exclusivamente para a cobertura de eventos e assuntos culturais do Rio de Janeiro, incluindo moda, teatro, música, cinema, religião, samba, ciência e seções dedicadas a segmentos de leitores, como a coluna "Gente Jovem".

Com a chegada de Alberto Dines na editoria do caderno, em 1965, o cinema passa a ter nova centralidade na cobertura diária. Cinéfilo desde a juventude, frequentador de cineclubes e dos cinemas da Cinelândia, o jornalista escrevia críticas no semanário Cena Muda, dedicado ao cinema e às artes do espetáculo. Depois passou a trabalhar como repórter para assuntos de cultura na revista Visão. No Jornal do Brasil, o seu pendor para o cinema foi fator de influência para as novas contratações de críticos e redatores. A cobertura dedicada à sétima arte também se amplia e inclui colunas fixas, como "Letreiro", com textos feitos no dia seguinte ao lançamento do filme no circuito, entre eles críticas com visões diferentes de um mesmo título. Dines também foi importante na promoção do Festival de Cinema de Curta-Metragem (Lima, 2006: 137).

O novo perfil do Jornal do Brasil trazia, portanto, uma visão que unia a valorização da cultura carioca à cobertura diária da cena cultural e do circuito exibidor. Entre os redatores, 
José Carlos Avellar, Miriam Alencar, Luiz Carlos de Oliveira Junior, Mauricio Gomes Leite e Ely Azeredo aliavam crítica cinematográfica à cobertura dos principais eventos da cidade, além de serem agentes importantes no meio cinematográfico da época. Ely Azeredo participou da criação do Cine Alvorada, espaço pioneiro na programação de filmes de arte no final dos anos 1950. José Carlos Avellar e Maurício Gomes Leite também viriam a dirigir filmes nos anos 1960.

Marcada por intensa cinefilia, a cobertura cinematográfica também testemunhava um circuito exibidor que passava por mudanças. No final dos anos 1950, surgem os primeiros cinemas de arte, como o Cine Alvorada, em Copacabana, criado por Ely Azeredo e Alberto Shatovski, importante exibidor do período. Tais espaços traziam para a sua programação filmes estrangeiros e de autores que não integravam as grandes cadeias de exibição. Além dos primeiros cinemas de arte, os cineclubes, muitos vinculados às universidades, também estavam em plena atividade. 0 Teatro Mesbla, local da primeira edição do Festival de Cinema Amador, sediava atividades dos diversos cineclubes em atividade na cidade. Em 1960, é inaugurado 0 Cinema Paissandu, mantido pela Companhia Cinematográfica Franco-Brasileira, que passou a programar filmes de Robert Bresson e da Nouvelle Vague francesa, incluindo diretores como Jean-Luc Godard, Jacques Rivette e Agnes Varda. As sessões eram precedidas por enormes filas e ávido interesse pela programação do cinema de arte.

Em 1964, o Paissandu, capitaneado pelo jovem programador Fabiano Canosa, egresso do Cine Alvorada, faz parceria com a Cinemateca do Museu de Arte Moderna (MAM) e passa a realizar sessões de clássicos do cinema com as cópias do acervo, organizadas com Cosme Alves Netto, diretor da Cinemateca do MAM. O Paissandu torna-se lugar central de encontro da juventude carioca e de gerações de cinéfilos. Entre alguns textos memorialísticos sobre tal circuito, destacamos aqui um trecho de memórias do escritor Ruy Castro:

0 quente eram as sessões de sexta e sábado à meia-noite, com os clássicos da Cinemateca do Museu de Arte Moderna cedidos por seu diretor Cosme Alves Neto, a pedido de Canosa. Nessas noites, que pareciam mobilizar le tout Rio, a aglomeração nos bares ao redor do cinema já começava por volta de 21 horas, provocada também pela presença quase certa dos rapazes do Cinema Novo, como David Neves, Cacá Diegues, Arnaldo Jabor, o dublê de jornalista e cineasta Mauricio Gomes Leite e, com direito a cadeira reservada, Glauber Rocha. Eles também eram cinéfilos, iam ao Paissandu para rever seus filmes do coração e, antes ou depois da sessão, pontificavam em voz alta no Oklahoma sobre os travellings, planos e contraplanos do diretor. (Castro, 2006: 406).

A Nouvelle Vague francesa e as discussões em torno do Cinema Novo brasileiro tiveram efeitos profundos nos espectadores e nos jovens realizadores que se formavam nas salas 
de cinema e nos cineclubes da época. Sem recair numa definição estética e formal unívoca do que foi o conjunto de filmes que integraram os dois movimentos citados, em linhas gerais podemos dizer que as novas ondas do cinema mundial alteraram os modos de produção, trabalhando com equipamentos mais leves, com filmagens fora dos estúdios e sem grandes equipes. 0 roteiro e a direção não estavam mais tão presos às estruturas mais clássicas de representação e decupagem, uma renovação de linguagem que também expressava o surgimento de diretores muito jovens já produzindo os seus primeiros longas-metragens.

No caso do Cinema Novo, filmes de diretores como Glauber Rocha, Joaquim Pedro de Andrade, Cacá Diegues, Ruy Guerra, entre outros, traziam uma nova visão sobre as questões sociais brasileiras e a forma de representá-las. Eram filmes marcados pela especificidade das experiências brasileira e latino-americana, como expresso por Glauber Rocha no manifesto "Uma estética da fome", de 1965:

A fome latina, por isto, não é somente um sintoma alarmante: é o nervo de sua própria sociedade. Aí reside a trágica originalidade do Cinema Novo diante do cinema mundial: nossa originalidade é nossa fome e nossa maior miséria é que esta fome, sendo sentida, não é compreendida. (Rocha, 1996: 126).

Tratar da fome e das disparidades sociais do Brasil significava também Ihe dar uma nova forma, uma nova imagem.

O Cinema Paissandu foi um espaço onde os filmes dessa geração tinham uma janela de exibição. Em depoimento, Fabiano Canosa, o jovem programador do Paissandu, mostra como o Cinema Paissandu também se conformava como um espaço de dupla resistência:

Assim que assumi a programação do Paissandu, procurei mitigar a falta de espaço regular para filmes Brasileiros serem apreciados: era o grande momento do Cinema Novo e assim sendo, programei "Deus e o Diabo na Terra do Sol", de Glauber Rocha, "Os Cafajestes", de Ruy Guerra, e "Vidas Secas", de Nelson Pereira dos Santos. Cumpríamos o chamado "oito por um" com uma seleção do que de melhor estava sendo feito no Brasil mas que, após sua exibição regular, nunca eram reprisados. No momento que vivíamos, com o trauma do regime autoritário e repressivo que nos tinha sido imposto, nossos cineastas e jovens, entusiasmados com os filmes e a movimentação, fizeram do cinema e dos bares ao seu redor um ponto de encontro (e de resistência). (Canosa: 2020).

Em meio à transformação no quadro das diretrizes estéticas e políticas do cinema dos anos 1960, a resistência à ditadura militar e os modismos de sua época, a Geração Paissandu, como ficou conhecida, veio a significar mais do que uma juventude cinéfila, expressando também transformações no campo dos costumes e comportamento, da moda, de revoluções estéticas no Brasil e no mundo. No samba "Garoto Paissandu", de Mariozinho Rocha, canta- 
do por Doris Monteiro, vê-se o reflexo do imaginário em torno dessa nova juventude (Durst, 1996: 5):

Garoto genial, de barba e de bigode

pra ser original, faz tudo quanto pode

na praia, ele anda quase nu

cinema só se for no Paissandu

Tem aula de inglês, no museu que é da imagem

e de som entende pouco, mas adora vernissage.

A ironia da canção faz coro com as diversas crônicas e matérias veiculadas no Jornal do Brasil nas quais a Geração Paissandu se tornara símbolo de uma juventude engajada, mas marcada pelas limitações de sua extração social, uma classe média retratada de forma caricata. Na sua múltipla feição, foi a cultura cinematográfica de uma época que veio a designar o espírito de uma geração.

É nesse contexto de transformação e efervescência cultural que se situa o Festival de Cinema Amador. A primeira edição, em 1965, voltou-se para as comemorações do IV Centenário. 0 certame tinha como tema obrigatório a cidade do Rio de Janeiro e foi realizado no Teatro Mesbla, empresa patrocinadora do festival e que possuía na época uma grande seção de vendas de equipamentos de fotografia e cinema amador. Com o sucesso da primeira edição, em 1966 o festival passou a aceitar inscritos de todo o país, estabeleceu equipes de seleção em diferentes estados e passou a ser realizado no Cinema Paissandu, inserindo-se no contexto da jovem cinefilia carioca.

Entre 1965 e 1970, o Festival de Cinema Amador JB/Mesbla, como ficaria conhecido, uniu uma geração de cineastas que seguiria longa carreira no cinema brasileiro, além de ter agregado a produção de jovens diletantes que tinham o cinema como forma de expressão de suas angústias existenciais e das reflexões sobre o seu tempo. Nele estrearam Rogério Sganzerla, Andrea Tonacci, Djalma Limongi Batista, Aloysio Raulino, entre outros, com curtas-metragens que centravam a sua energia na expressão das questões estéticas impostas pelo cinema moderno e dos dilemas políticos enfrentadas por uma geração. Tendo a sua primeira edição um ano após o início do período ditatorial no país, o festival recebeu muitos filmes que dariam imagem ao clima sufocante que passava a tomar conta do país.

Nas matérias dedicadas ao festival e a uma nova geração que ali despontava também é possível perceber a ênfase na juventude, nos novos caminhos estéticos e nas transformações do fazer cinema no Brasil. Sob a égide da modernização e da inovação, o cinema amador foi um locus privilegiado para a expressão do novo lugar dado ao cinema na cultura brasileira e do imaginário em torno de uma juventude que, com a facilidade propiciada pela produção de filmes em pequenos formatos, passava a ter o cinema como forma de expressão (Figura 1). 


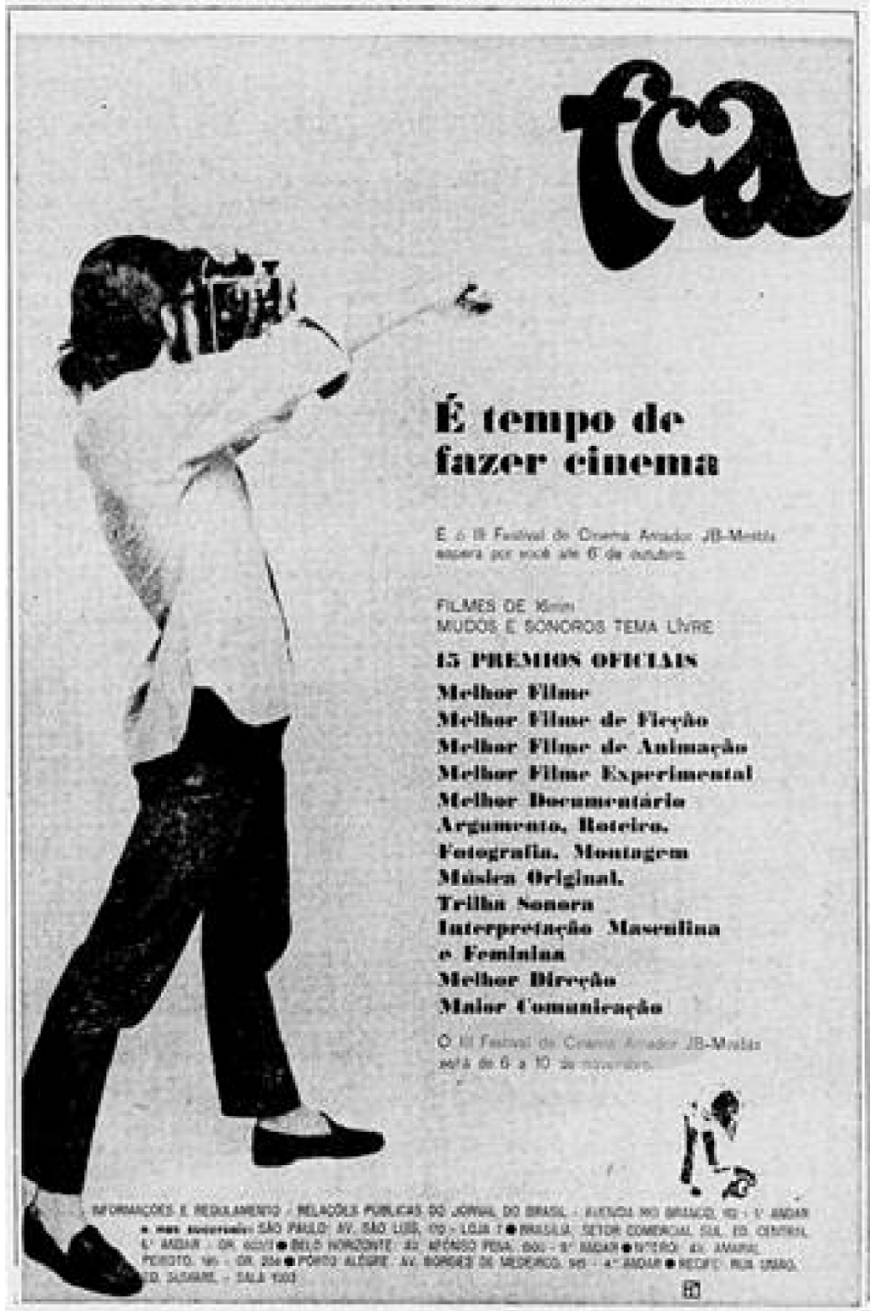

Fonte: Hemeroteca Digital Brasileira - Biblioteca Nacional.

Figura 1 - "É tempo de fazer cinema" - No anúncio do III Festival de Cinema Amador um jovem, com uma câmera na mão, parece apontar para o futuro. (Jornal do Brasil, n. 127, 2 set. 1967: 19).

\section{JUVENTUDE EM MOVIMENTO}

$\mathrm{E}$ m 1962, Edgard Morin publicou o primeiro volume de Cultura de massa no século XX, obra que buscou dar conta da nova configuração social e cultural que eclodiu em meados do século XX. Sociólogo do presente, o autor visou destrinchar os fatores de uma transformação que estabeleceu novos valores para a cultura do período, transformação na qual os 
veículos de comunicação de massa, como o rádio, a televisão e o cinema, tiveram fundamental centralidade. Debruçando-se sobre o contexto do pós-guerra estadunidense e europeu, 0 autor afirma:

A cultura de massa é uma cultura: ela constitui um corpo de símbolos, mitos e imagens concernentes à vida prática e à vida imaginária, um sistema de projeções e identificações específicas. Ela se acrescenta à cultura nacional, à cultura humanista, à cultura religiosa e entra em concorrência com estas culturas. (Morin, 1997: 15).

Nesse cenário de desestabilização dos valores ditos tradicionais, como a família, a igreja e a escola, imprensa e cinema passam a ser dominantes na configuração de valores das dinâmicas social e cultural. No mesmo livro, o autor francês identifica um conjunto de valores da cultura de massa que passam a nortear tais imaginários, entre os quais está juventude. A valorização da juventude não estava necessariamente restrita ao recorte de uma faixa etária que iria dos 15 aos 25, da adolescência ao jovem adulto, mas insuflaria a cultura como um todo. Essa apreciação traduziria o espírito do tempo, "relacionado às rupturas, ao novo, ao que não se conforma, à busca por experiências e mudanças" (Enne, 2010: 19).

Os anos 1960 consolidam, portanto, um movimento social no qual a juventude se torna um valor que engendra também uma cultura jovem dotada de ares de mitologia, nesse período um imaginário plenamente incorporado pela mídia: "os jovens do pós-guerra vivenciavam um momento de construção de identidade grupal e, como tal, encontravam uma inédita visibilidade, graças à vertiginosa influência dos meios de comunicação de massa" (França e Pereira, 2012: 178). Será na relação entre o cinema e a imprensa que poderemos localizar a construção de um imaginário em torno da juventude como valor de transformação e rebeldia, traço que permeia os filmes e as páginas dos jornais.

Segundo o historiador Eric Hobsbawm, para a compreensão da revolução cultural que eclode nos anos 1960, "a melhor abordagem dessa revolução cultural é [...] através da família e da casa, isto é, através da estrutura de relações entre os sexos e gerações" (Hobsbawm, 1995: 250). No período pós-guerra, as estruturas familiares sofreram mudanças e o lugar da autoridade patriarcal viu-se abalado, tanto no papel das mulheres na manutenção da casa e criação dos filhos quanto nas relações de poder entre pais e filhos. Não por acaso, a crise entre a obrigação social — de se casar virgem, de obedecer às decisões dos pais quanto aos rumos a serem tomados pelos filhos - será tema central do cinema hollywoodiano nos anos 1950 e 1960, em filmes como Juventude transviada (Nicholas Ray, 1955) e Clamor do sexo (Elia Kazan, 1961). James Dean foi a figura ícone na sedimentação desse imaginário de uma 
juventude que ia contra os valores tradicionais, de uma rebeldia que podia tanto ser libertadora quanto sedimentar um senso de angústia e inadequação.

Era o cinema que dava imagem e corpo a uma juventude transgressora e alimentava o culto a esse imaginário. A disputa entre gerações, que preconizava novas formas de relação com o mundo e com a arte, também insuflaria o trabalho dos jovens cineastas e dos personagens dos filmes da Nouvelle Vague francesa, que se tornou uma espécie de matriz e fonte de inspiração para uma geração de cinéfilos e cineastas brasileiros. Num movimento que ia de encontro à tradição do cinema francês - com roteiros de matriz literária, altos orçamentos e filmagens em estúdios — os denominados jovens turcos renovaram os moldes de produção com filmagens nas ruas da cidade, câmera na mão, baixos orçamentos e novos personagens.

Para citar somente os dois filmes mais icônicos dessa mudança: Os incompreendidos (François Truffaut, 1959) e Acossado (Jean-Luc Godard, 1960). No primeiro, é uma crise com a escola disciplinar e a estrutura tradicional de formação e, no segundo, um jogo com os ícones da juventude que aparece na tessitura narrativa e estética. Se o primeiro vai ter a demolição dos antigos valores como tema, o segundo já incorpora a imprensa e o cinema como meios de comunicação e formação do imaginário do seu tempo. Jean Seberg e Jean Paul Belmondo vão encarnar os modos de um novo cinema.

Godard será também uma figura icônica para os cinéfilos dos anos 1960. 0 diretor francês dava o tom de um cinema moderno, que mudava as regras do jogo da representação cinematográfica, tornando-se ele mesmo um símbolo do que havia de novo e radical em um artista. A juventude retratada nos filmes também afirmava um estilo de vida, com sua ética, códigos sociais e formas de estar no mundo (moda, gostos, hábitos) (Figuras 2 e 3).

Os jornais também estavam atentos aos movimentos culturais que eclodiam nos anos 1950 e 1960, davam-Ihes forma e valiam-se do valor simbólico agregado às publicações por fazerem parte das transformações em curso. A própria Nouvelle Vague francesa, seu conceito e ideário, é um fenômeno que se forma nas páginas da imprensa.
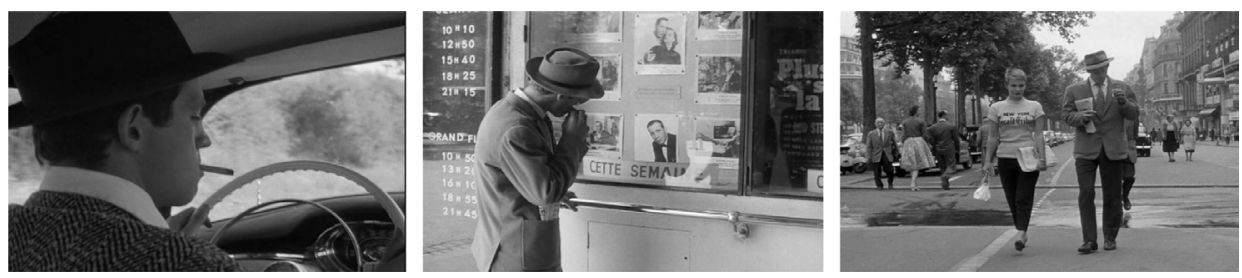

Figura 2 - Automóveis, cinefilia e o jornal: o cotidiano em Acossado (1959). 


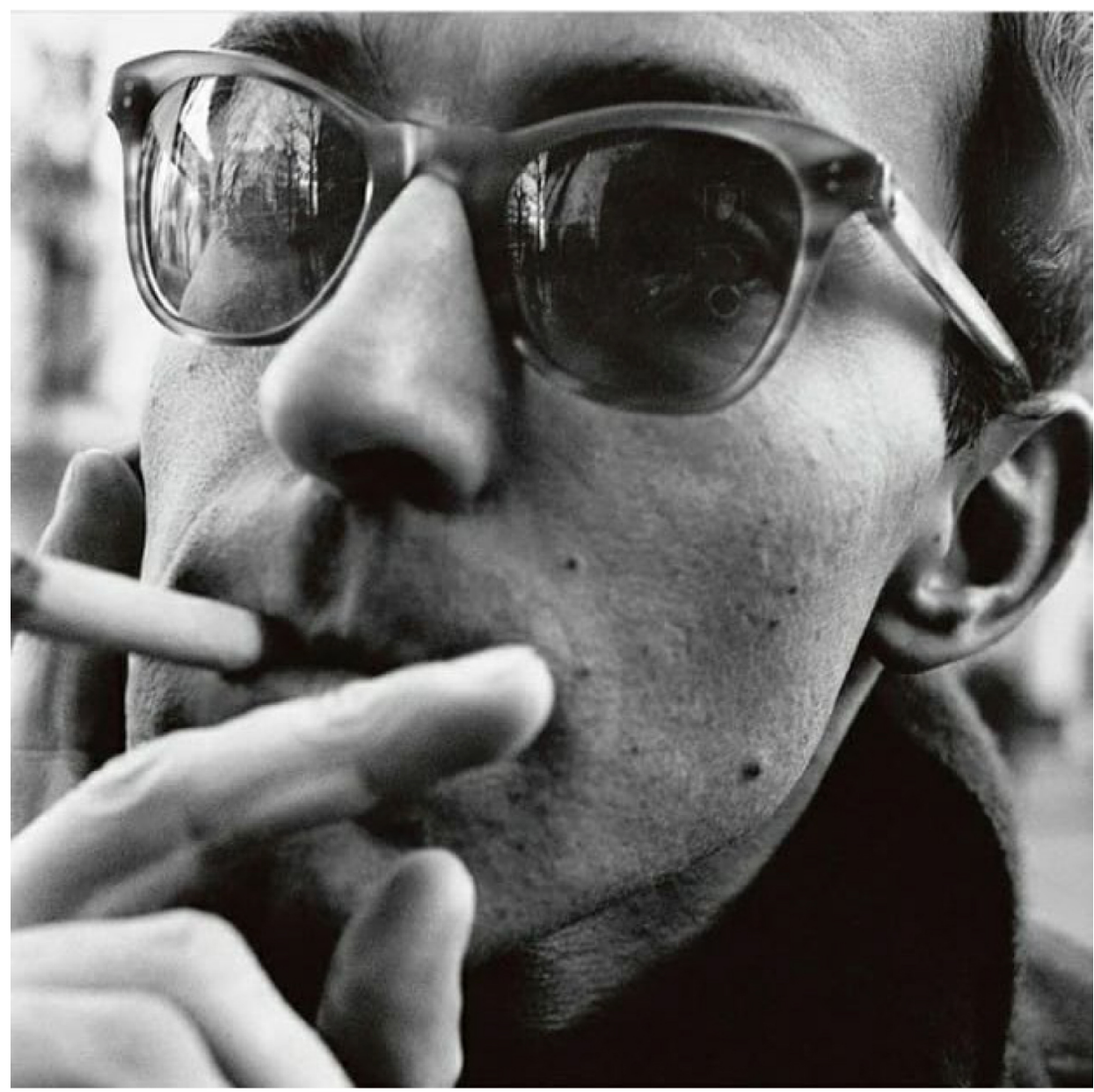

Figura 3 - Jean Luc-Godard, ícone da Geração Paissandu.

A expressão "nouvelle vague" está historicamente associada a um certo período do cinema francês, em torno dos anos 1959-1960. No começo não passava de um simples rótulo jornalístico. Surgiu de um contexto externo ao cinema, que refletia uma pesquisa de opinião publicada pelo semanário político e cultural L'Express sobre a juventude francesa em novembro de 1957. (Marie, 2003: 167).

Nesse período, cinema e imprensa são, portanto, inseparáveis na configuração do novo, transformando o que poderia ser disforme e disperso em processos dotados de certa unidade de características, personagens, imagens e imaginários. Noticiar o novo, simbolizado principalmente pela adesão à cultura jovem, era também uma forma de tornar os jornais mo- 
dernos, porta-vozes da transformação. Nas páginas do Caderno B do Jornal do Brasil, o interesse pela cultura juvenil estava sempre presente nas crônicas, nas dicas de moda, nas colunas sociais. A coluna "Gente Jovem", assinada por Carlos Eduardo, trazia notas e fotografias de garotos e garotas empunhando violões, a juventude bossa-nova, jovens modelos nas praias, noivas rumando para o primeiro casamento, jovens motociclistas e cabeludos (Figuras 4 e 5).

Com o cinema não seria diferente. Em conjunto com as inovações do Caderno B e a nova centralidade dada ao cinema, o Jornal do Brasil também expressava a consciência da incisão que tinha na promoção da cultura cinematográfica da época. 0 primeiro caderno do dia 13 de maio de 1966 trazia os seguintes dizeres:

O Jornal do Brasil foi o primeiro da imprensa a publicar uma coluna dedicada exclusivamente ao cinema. O JB lançou a expressão cinema novo - para identificar o movimento que criou o cinema moderno brasileiro - marca atual de todos os movimentos de renovação do cinema mundial. O JB promoveu — e continua promovendo — o Festival de Cinema Amador, a primeira escola viva de cinema do Brasil [...] o JB está incentivando, na teoria e na prática, a revolução do cinema brasileiro verdadeiramente nacional em técnica e arte. (Jornal do Brasil... 13 maio 1966: 9).

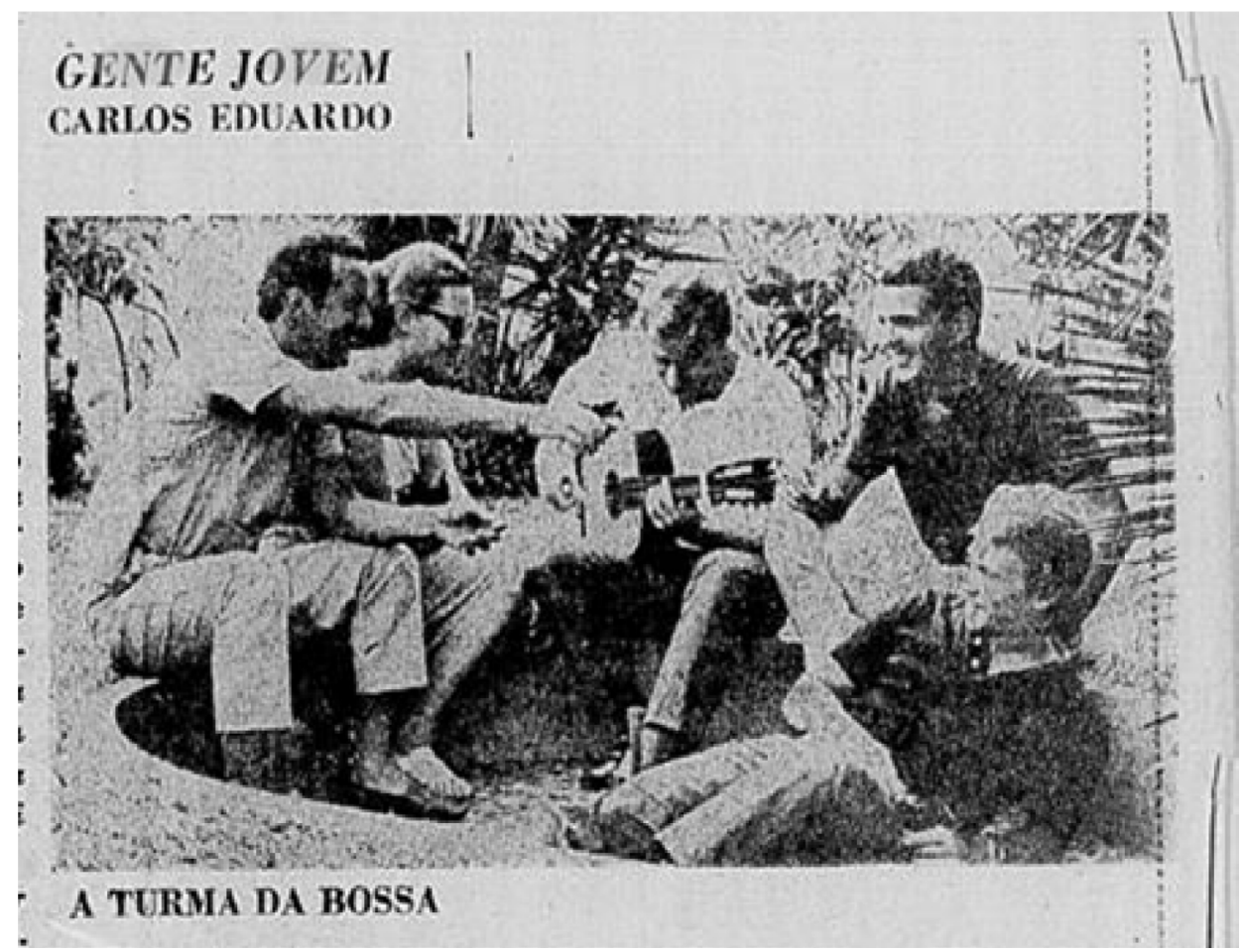

Figura 4 - "A turma da bossa" - A bossa nova era símbolo do moderno na música brasileira e a juventude carioca já estava a ela incorporada. (Jornal do Brasil, 17 jan. 1965: 3). 


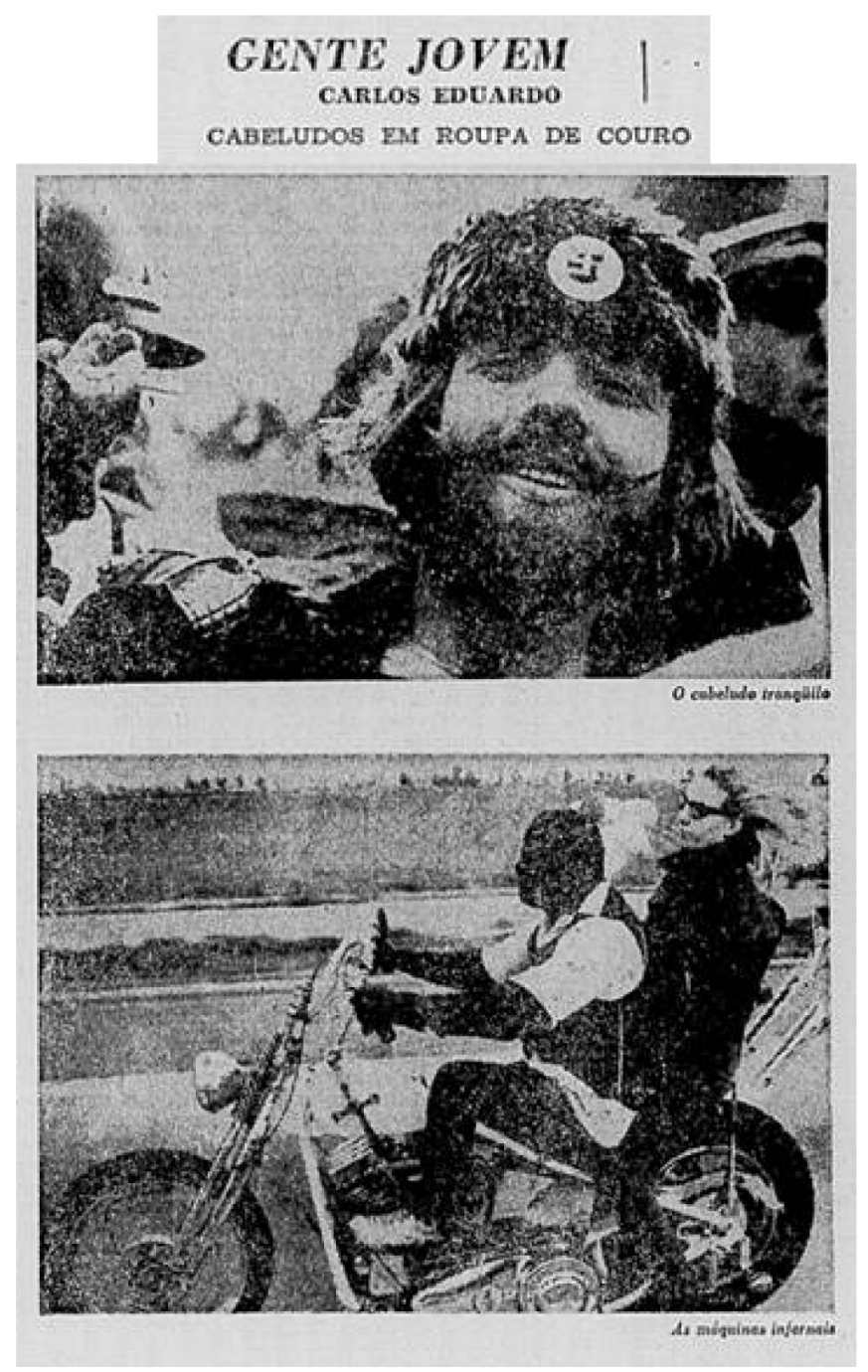

Fonte: Hemeroteca Digital Brasileira — Biblioteca Nacional.

Figura 5 - "O cabeludo tranquilo" e "As máquinas infernais" — A liberdade e a rebeldia expressas no corpo e nos modos de vida. (Jornal do Brasil, 6 mar. 1966: 2).

A renovação do cinema mundial e brasileiro dava a tônica de muitos dos textos sobre o cinema que estavam sendo produzidos no Brasil em meados dos anos 1960. Esse discurso também permeava a cobertura do Festival de Cinema Amador e as expectativas em torno do evento e dos jovens realizadores que dele participavam. Após o sucesso da primeira edição em 1965, os preparativos para a segunda edição incluíam notícias sobre os realizadores que 
produziam os seus filmes para o festival. No incentivo à produção e descoberta de novos talentos, a Nouvelle Vague francesa e o Cinema Novo eram pontos de referência e inspiração da "novíssima geração", termo que Miriam Alencar, repórter cinematográfica do Jornal do Brasil, cunhou para designar o trabalho de "realizadores que pisavam num terreno quase de sonho" (Alencar, 1978: 96).

Em 1966, Alencar publica "Nasce um cinema com o Festival JB" (Jornal do Brasil, 30 jun. 1966a: 5), acompanhando a produção de filmes por jovens cineastas. No destaque dado aos cineastas paulistas, todos voltados "para o problema existencial de São Paulo", a jornalista acompanha o trabalho de Andrea Tonacci e Rogério Sganzerla. No artigo, veem-se fotos dos jovens cineastas em ação na filmagem de Documentário (1966), dirigido por Sganzerla e fotografado por Tonacci, e Olho por olho (1966), dirigido por Tonacci e montado por Sganzerla (Figura 6).

Para os dois diretores, o Cinema Novo propiciou uma abertura no campo cinematográfico brasileiro. Em depoimento dado na mesma época, Andrea Tonacci reconhece a sua filiação:

Faço parte de um Cinema Novo porque descendo dele. 0 Cinema Novo abriu a visão nacional das coisas, dos problemas políticos, sociais, econômicos, sem sair do campo brasileiro. No Brasil, não estamos em condições de ser especialistas dentro do cinema. Tudo deve ser rápido, até 0 modo de ver e sentir: chegar à compreensão no momento da aceitação. (apud Ferreira, 2000: 34).

Para além da filiação com o cinema que o antecedia, ali se gestava o caminho de um cinema urbano, disposto a captar o fluxo espontâneo das ruas sem a necessidade de roteiros ou grandes equipes. Esse cinema fincado no acontecimento tinha jovens como personagens
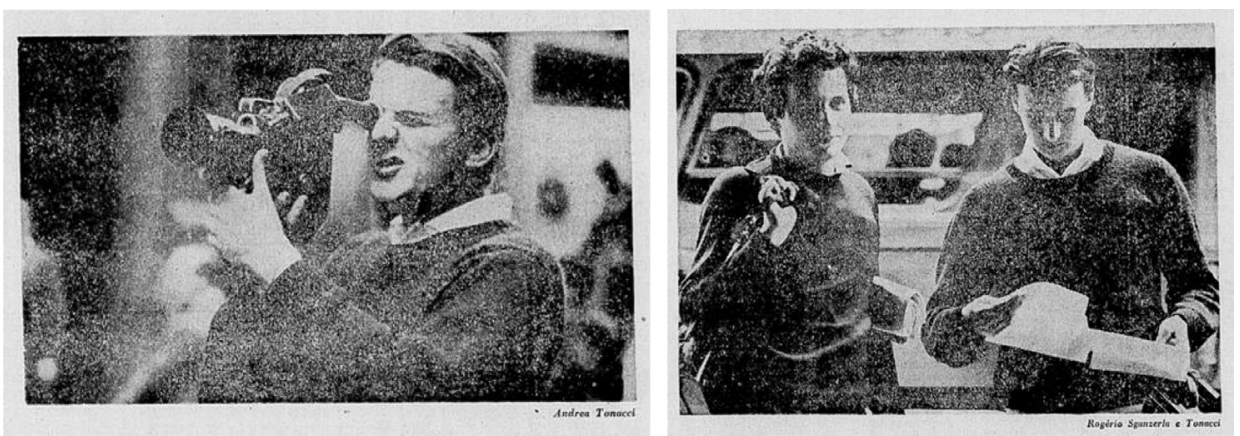

Fonte: Hemeroteca Digital Brasileira — Biblioteca Nacional.

Figura 6 - Os jovens Rogério Sganzerla e Andrea Tonacci filmam nas ruas de São Paulo. (Jornal do Brasil, 30 jun. 1966a: 5). 
principais e refletia sobre a experiência de uma juventude urbana, enfrentando os primeiros anos do regime ditatorial no Brasil. Em 1966, três filmes trariam na sua forma e no seu conteúdo esse gesto de um olhar-câmera atento à fachada das coisas, não sem dar contornos para o clima de angústia que tomava conta da juventude brasileira: os dois já citados Olho por olho e Documentário, além de 0 bem-aventurado, de Neville D'Almeida, curtas de destaque da segunda edição do festival de cinema amador e que possuem cópias disponíveis para visionamento.

Na matéria de balanço do ano de 1966 intitulada "O cinema mais jovem" (Jornal do Brasil, 28 dez. 1966) e assinada por Maurício Gomes Leite, os três diretores recebem destaque e dão voz às suas preferências cinematográficas. Entre as mais citadas estão Jean-Luc Godard, o fotógrafo dos seus filmes, Raoul Cotard, e cineastas do Cinema Novo (Figura 7).

\section{O CINEMA MAIS JOVEM}

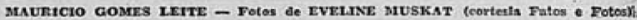

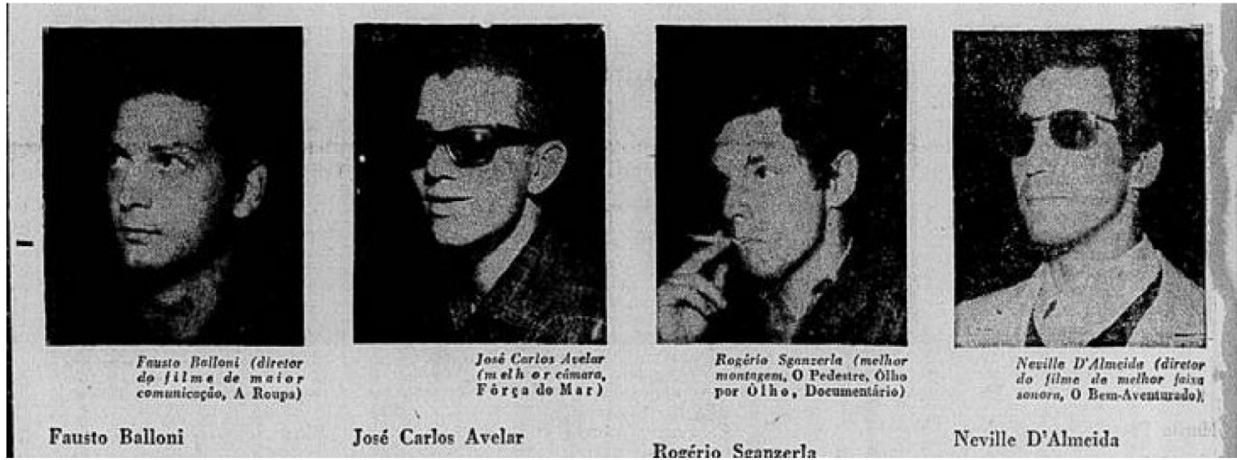

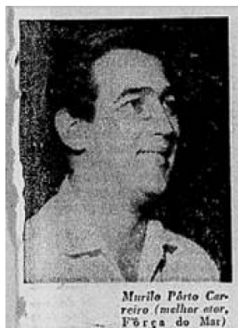

Merrilo Pòrto Carreiro

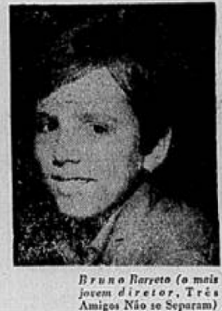

Bruno Barreto

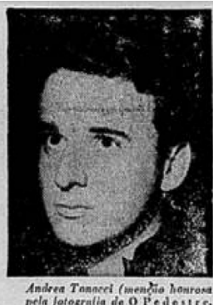

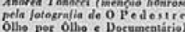

Andren Tonacei

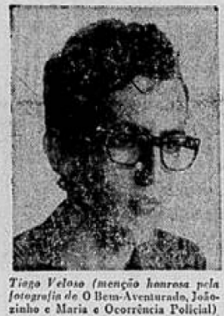

Tiago Veloso

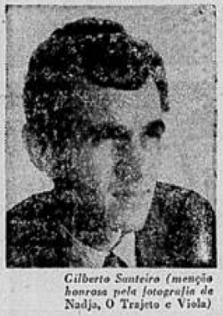

Gilberto Santciro

Fonte: Hemeroteca Digital Brasileira — Biblioteca Nacional.

Figura 7 - Os óculos escuros e o cigarro na boca à la Godard são índices de uma juventude que também se quer moderna. (Jornal do Brasil, 28 dez. 1966: 4). 


\section{CINEMA E JORNAL, UM MERGULHO NO TEMPO PRESENTE}

N primeiro ano, os filmes participantes do Festival de Cinema Amador tinham uma de Escravos de Jó, dirigido por Xavier de Oliveira e vencedor da primeira edição. Filmado em uma favela carioca, o curta acompanha a vida de crianças na sua luta pela sobrevivência e aproxima-se da estética do Cinema Novo, mas não sem trazer traços de experimentação e fantasia. Os filmes que integraram a edição de 1966 trazem jovens cineastas que figuram os seus dilemas, expressão do tempo vivido da juventude.

De São Paulo, três foram os filmes de destaque: Olho por Olho de Andrea Tonacci, Documentário de Rogério Sganzerla e O pedestre de Otoniel Santos Pereira, todos produzidos com rodízio de equipes: Tonacci como câmera e fotógrafo usando uma Bolex $16 \mathrm{~mm}$ e Sganzerla montando os filmes com uma moviola $16 \mathrm{~mm}$ que possuía. Neville D'Almeida, membro do Centro Mineiro de Cinema Experimental (CEMICE), também participa com o curta 0 bem-aventurado. Vistos em conjunto, os filmes apontam para uma aproximação com 0 cinema moderno e a expressão das agruras de uma juventude vivendo no Brasil pós-golpe. Trata-se de um cinema construído como experiência, com uma câmera na mão que acompanha o movimento das cidades, que não resguarda distância entre quem filma e quem é filmado e que dá vazão à expressão de diferentes matizes da cultura jovem.

Na época, Tonacci era estudante de Arquitetura e Sganzerla estudava Direito no Mackenzie, já contribuindo com críticas para jornais desde os 17 anos, a começar pelo renomado "Suplemento Literário" de 0 Estado de São Paulo, editado por Décio de Almeida Prado. Geraldo Veloso, cineasta mineiro, recorda em Por uma arqueologia de um outro cinema o encontro com os dois jovens cinéfilos:

Pouco tempo depois, numa daquelas noites quando começava a "febre Paissandu", com sessões de sexta-feira, às dez da noite, programadas por Fabiano Canosa para a Cinemateca, em colaboração com o cinema dos irmãos Valancy, no Flamengo, que tanto marcou uma geração e que logo evoluíram para pré-estreias à meia-noite [...] Geraldo Mayrink me apresenta a dois paulistas "malucos" que estavam filmando coisas geniais. Era uma sessão de Pierrot le fou e Rogério, acompanhado de Andrea Tonacci, tinha vindo de São Paulo exclusivamente para ver o filme. Rogério montava o filme de Tonacci (Olho por Olho) e Tonacci fotografava o filme de Rogério (Documentário). (Veloso, 1983).

Sganzerla vivia a intensa cinefilia do período e Documentário traz a marca dessa vivência: os jovens atores que caminham pelo centro da cidade em busca de um filme interessante ao qual assistir, as bancas de jornal e suas revistas em quadrinhos, os posters dos filmes do Godard e do cinema de gênero que tomam as fachadas dos cinemas populares (Figura 8). 

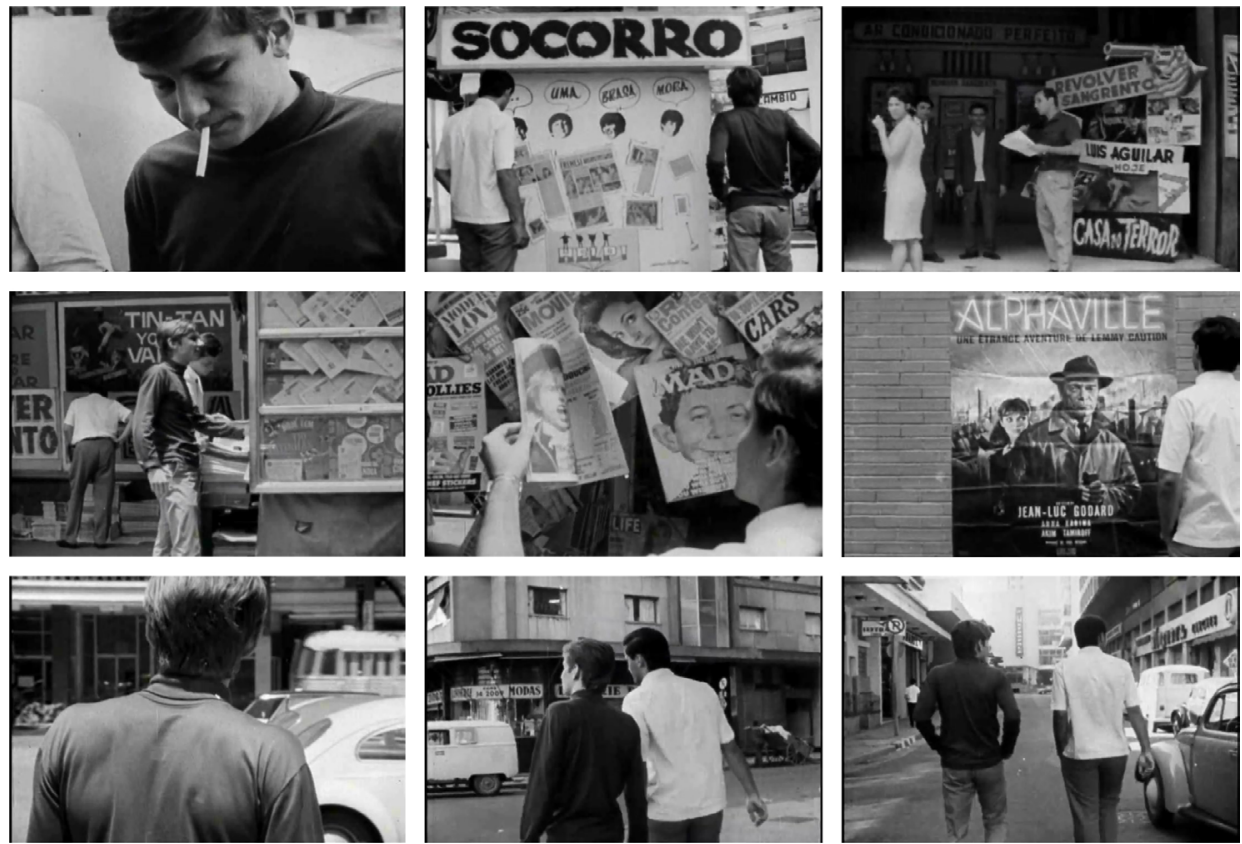

Figura 8 - Um passeio pela cidade e pelas referências de dois homens jovens paulistanos em Documentário.

No artigo "As promessas do tédio e da coragem", de Miriam Alencar, Sganzerla narra o processo de produção:

No ano passado, Maurice Legeard veio de Santos e me deu algum dinheiro para eu filmar o que quisesse. Resolvi fazer uns $16 \mathrm{~mm}$. Os atores foram dois amigos meus a quem recorri de última hora. Dei a câmera a Andrea Tonacci, que é apaixonado por fotografia. Ele nunca tinha feito nada em $16 \mathrm{~mm}$ e realizou um trabalho excepcional, como eu queria: tons claros, contrastados, simples e requintados. A fotografia é a melhor coisa do filminho que ainda não está sonorizado — não tenho produção nem muito dinheiro, por isso, tudo vai devagar. Foi totalmente rodado nas ruas de São Paulo com paupérrimos recursos. Gosto, entretanto, do que fiz porque seus 14 minutos estão narrados com mise-en-scéne. (Jornal do Brasil, 1 jun. 1966b: 8).

0 cinema improvisado, feito com parcos recursos, dá o tom das filmagens. Nas imagens publicadas no Jornal do Brasil, as legendas "a faixa mais jovem do cinema paulista" e um "cinema das criaturas comuns" acompanham as imagens da filmagem do primeiro curta de Sganzerla (Figura 9).

Documentário é um espelhamento da própria vivência na cidade, as obsessões da juventude como as revistas em quadrinhos e o amor ao cinema. A direção explora e intensifica 

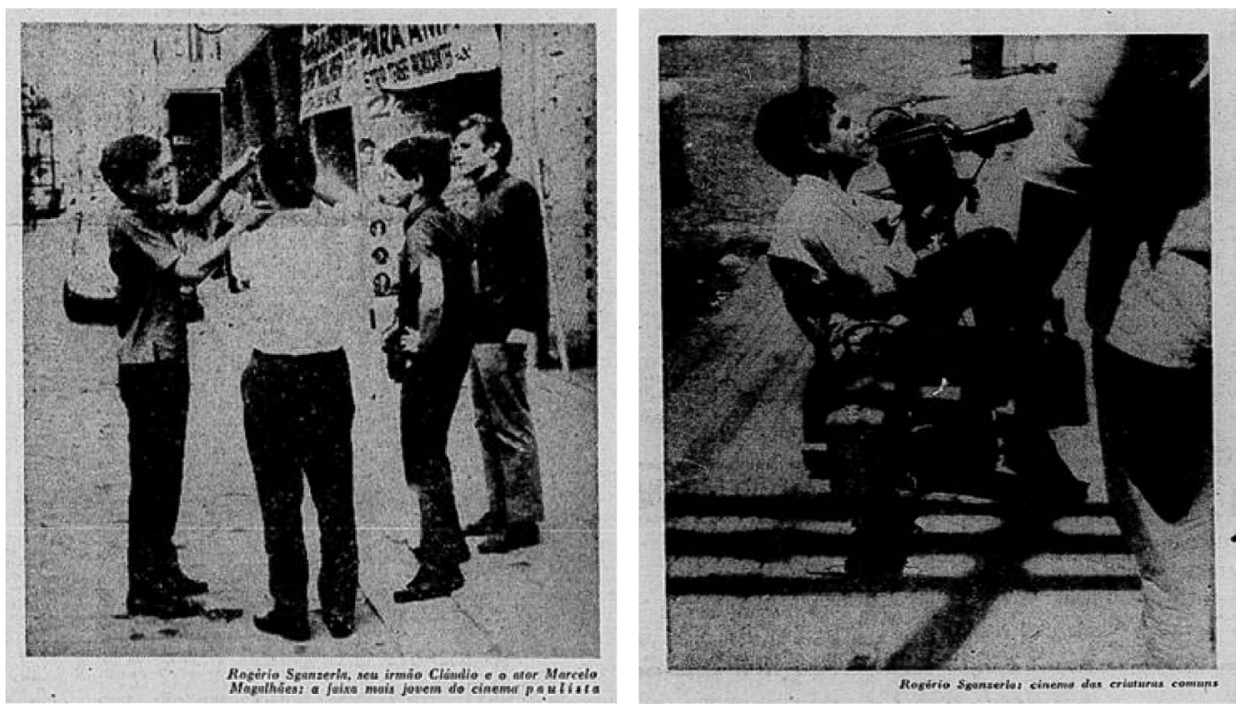

Fonte: Hemeroteca Digital Brasileira - Biblioteca Nacional.

Figura 9 - Filmagens no centro da cidade de São Paulo. (Jornal do Brasil, 1 jun. 1966b: 8).

a ideia de um cinema-experiência, marcada principalmente pela câmera que deambula junto com os personagens, acompanhando-os de perto. Como fruto do cinema moderno de matriz godardiana, no qual se explora o uso da câmera na mão em um cinema autorreflexivo, a conexão entre quem filma e quem é filmado fica ao final mais evidente, quando ouvimos as vozes de Sganzerla e Tonacci comentando a feitura do filme. Eles falam sobre o gesto de heroísmo dos dois jovens por filmarem sem ter conhecimento nem dinheiro, sobre as dificuldades técnicas e de produção.

Nas palavras de Sganzerla, "no final das contas é um documentário sobre dois rapazes trabalhando num filme amador" ("Nasce um cinema com o Festival JB", Jornal do Brasil, 30 jun. 1966a: 5). Sobre Acossado, Godard também afirmou que "era um documentário sobre Jean Seberg e Jean-Paul Belmondo" (apud Baecque, 2010: 328). Tanto o título do curta-metragem como a sua forma sugerem um cinema ficcional colado ao tempo vivido, destituído de muitos artifícios, permeado de gestos cotidianos: ir ao cinema, andar pelas ruas, consultar o jornal. Talvez por isso a ideia de que a captura desse fluxo se aproxime de uma espécie de documento da juventude de uma época.

Olho por olho, com Tonacci na direção e na fotografia e Sganzerla na montagem, produz um interessante contraponto. Aqui se mantém uma mise-en-scène centrada na constituição de um senso de experiência, em detrimento de uma atenção marcada pela narrativa 
mais estruturada, errância que se combina, novamente, com a questão existencial de um dia sem nada para fazer vivido por um grupo de jovens. Em Olho por olho o percurso do dia é feito dentro de um carro por jovens que vão dirigindo pela cidade, aparentemente sem motivo (Figura 10). A montagem ágil de Sganzerla repica o tempo vivido, num ritmo que se intensifica com o som do rádio, que salta entre o rock, a música popular brasileira, o noticiário e discursos políticos. Há aqui mais ritmo, mas também mais tensão entre esses jovens à deriva, que vão embarcando no carro sem um direcionamento preciso.

0 que pesa como diferença é que os jovens desse curta-metragem claramente expressam o caráter violento de uma parcela da juventude do período. Em Olho por olho, entre músicas de Chico Buarque, Rolling Stones e Beatles, um pronunciamento no rádio defende uma democracia contra a esquerda, contra a direita, "uma democracia por Deus, com Deus e pelo povo". No carro, um dos jovens repete frases de violência e extermínio: "dá uma olhada nessa gente, precisa acabar com esse negócio", "precisa acabar com essa palhaçada", "precisa mudar tudo", "precisa matar, isso sim", "precisa dar uma peste bubônica, matar com tudo".

A violência eclode, de fato, no final. Em Olho por olho, que preconiza o revide da violência na mesma medida, a ação sem rumo dos jovens culmina em um ato de agressão gratuita. Uma mulher que faz parte do grupo de jovens desce do carro e é usada como isca para atrair um homem que dirige pelo centro. Ela entra no carro e eles dirigem pela cidade com 0 carro dos jovens no seu encalço. Ao entrar numa rua, como que numa emboscada, o moto-
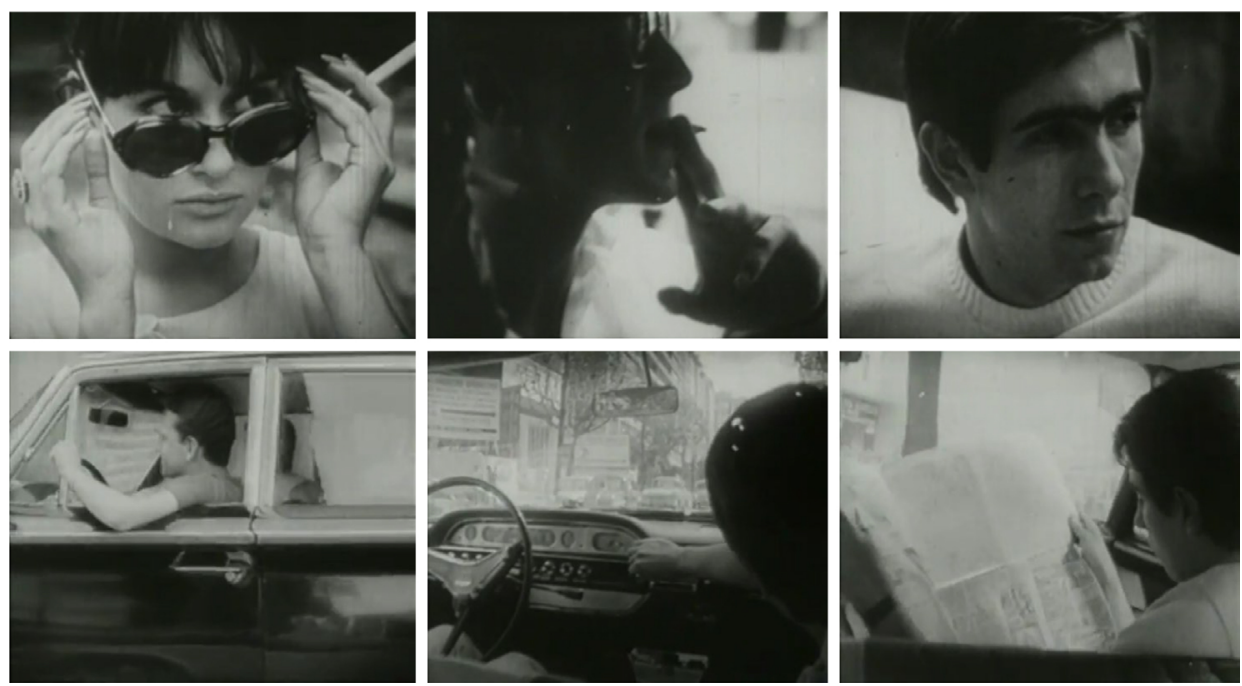

Figura 10 - Juventude encerrada no ambiente de um carro em Olho por olho. 
rista para o carro e é retirado dele violentamente, sendo espancado no meio da rua. 0 que se encena é um jogo violento que parece rotineiro, já que todos sabiam qual papel exercer.

Se por um lado o ideário em torno da juventude evoca um senso de liberdade, de novos modos de vida, existe também a dimensão delinquente, de rebeldia sem direcionamento preciso, restando o puro ato violento sem motivação. Ao dar forma à gratuidade da violência, o filme parece responder ao clima de desolação diante de um regime autoritário, que já estava instalado no cotidiano e se tornaria cada vez mais violento na repressão a artistas e intelectuais.

A angústia também toma forma de explosão de violência em $O$ bem-aventurado, de Neville D'Almeida, rodado em Belo Horizonte. Novamente, um jovem deambula pela cidade sem ter uma motivação evidente. É a própria cidade que traz a dimensão dos conflitos ideológicos vividos no período. Na fachada de um prédio, em grandes letras, vemos um anúncio assinado pelas "Associações Democráticas". Os dizeres descrevem a vida na cidade caso Belo Horizonte fosse dividida, assim como Berlim, com muros e arames farpados: "Berlim (ou Vietnã, ou Cuba) não é tão longe! Será que a Revolução de 31 de março não evitou muita coisa?". Parado diante de uma banca, o personagem lê as manchetes de jornal, que noticiam as tensões sociais do período. Na Tribuna da Imprensa se lê: "Nação não tem segurança" e "Violência: estudantes saem às ruas".

Depois de andar pelas ruas da cidade, o jovem entra em uma grande loja de departamentos com suas escadas rolantes e anúncios, um espaço saturado de produtos e anúncios visuais. Passeia pelos corredores, assiste a um desfile de moda, pede para ver uma arma que está à venda na vitrine. Com a arma em punho, gesticula como se estivesse atirando em um anúncio exposto com a imagem de uma família tipicamente burguesa: mãe, pai e filhos sentados numa praia ensolarada. Essas imagens dão conta da saturação dos códigos da cultura do consumo e da proeminência da publicidade nesse cenário cultural-midiático; são imagens vistas como caricatas, um imaginário a ser atacado. Continuando a sua errância, ele entra em uma livraria e tenta roubar um livro levando-o embaixo da camisa. 0 livreiro percebe 0 ato de infração e acompanha-o discretamente. Antes de sair da loja, ele devolve o livro jogando-o contra o livreiro, como se arremessasse uma bomba. Corre e, tomado de fúria, começa a chutar o tapume de uma obra. Logo é perseguido e preso por dois policiais, que o arrastam pelas ruas da cidade.

Novamente, uma ação que não tem fim e a falta de rumo revelam a tônica desses três curtas-metragens que têm jovens como personagens principais. 0 jornal e o rádio serão os porta-vozes do estado das coisas no país, permitindo ver uma nova ordem política e social na dinâmica do cotidiano. Em Documentário, um personagem lê o Jornal da Tarde cuja manchete 
diz: "Subversão está voltando". Em 0 bem-aventurado, as manchetes dos jornais também refletem as tensões vividas no pós-golpe. 0 som do rádio em Olho por olho é incessante e ocupa todo o espaço do filme.

Nesses filmes, os meios de comunicação são também personagens, mostrando o lugar da cultura midiática no cotidiano e como interesse especial do cinema. Se os filmes do pós-golpe dos integrantes do Cinema Novo concentram a sua atenção na crise do jornalista-intelectual e nas salas de redação - Marcelo em O desafio (Paulo César Saraceni, 1965), Paulo Martins em Terra em transe (Glauber Rocha, 1967) e Estevão em A vida provisória (Maurício Gomes Leite, 1968) — os curtas da "novíssima geração", por outro lado, darão atenção a outras dimensões dos meios de comunicação, às interferências das ondas do rádio, à publicidade, aos gibis. São temas e formas também presentes nos filmes que sucedem a iniciação dos diretores que estrearam no Festival de Cinema Amador de 1966. De certa maneira, a mídia, incluindo rádio, televisão e cinema, seus discursos e sua estética são fundamentais para a estruturação de Blá, blá, blá (1968), de Andrea Tonacci, com o político discursando em meio à aparelhagem da arena midiática. Em $O$ bandido da luz vermelha (1968), de Rogério Sganzerla, a vida de um bandido é contada como um folhetim nas ondas do rádio.

De um lado, os curtas da "novíssima geração" condensam uma resposta estética à deriva e a angústia de uma juventude que vivia os primeiros anos da ditadura civil-militar instalada em 1964. De outro, são expressões de uma nova compreensão sobre o fazer cinematográfico e a noção de espontaneidade. A câmera está presente junto aos seus personagens, em meio à rua, captando uma pulsão do tempo presente. Não por acaso, os jornais sempre aparecem, elementos corriqueiros, mas que dão uma dimensão mais marcada do tempo histórico vivido.

Mas é uma nova noção de temporalidade que surge nos curtas-metragens, que já se sedimenta em tempos mais instáveis. Os jovens retratados não parecem ser símbolos de uma geração, mas retratos parciais de uma juventude em tempos de incertezas. A deriva de jovens cinéfilos, a deriva de jovens conservadores, a deriva de um jovem solitário. Se a crise do jovem intelectual no Cinema Novo é a crise de uma perda e o vazio que dela decorre, os curtas-metragens aqui analisados dão conta da experiência de um tempo já esgarçado pela tensão imposta pelo regime militar.

Se o jovem intelectual do Cinema Novo olha para si, o olhar dos jovens cineastas e seus personagens estão mais atentos ao fluxo do mundo, à energia das cidades, aos reclames, às notícias de jornal, aos outdoors. A deambulação e a caminhada pela cidade são também formas de direcionamento do olhar para as coisas do mundo. Em uma das entrevistas concedidas a Miriam Alencar, Tonacci explica o recurso a um cinema que usa a câmera "como se usaria um par de óculos, unicamente para ver": 
Olhar para esse plano como se olha para um jornal, folheá-lo, ler as manchetes, ver essa fachada das coisas, essa folha plana onde ocorrem os fatos independentemente de suas razões, nos mínimos detalhes complexos e absurdos por não precisarem de uma explicação, bastando o acontecimento. (Jornal do Brasil, "As vozes de São Paulo", 31 maio 1966c: 8).

Cinema e jornal amalgamam-se, portanto, no registro de uma realidade em camadas e multifacetada nos sentidos dados aos acontecimentos do mundo. Nesses três curtas-metragens podemos ter uma ideia do clima de deriva que pairava na juventude que começava a trilhar os seus primeiros passos na prática cinematográfica, um cinema já com referências, mas que também forjava novas respostas ao tempo vivido. As imagens que circundam o festival de cinema amador do Jornal do Brasil também expressam as diversas matizes do ser jovem nos anos 1960: a Nouvelle Vague como forte referência imagética na conformação de um novo imaginário sobre as questões da juventude, as inovações no campo cultural brasileiro, incluindo a Bossa Nova e o Cinema Novo, a cinefilia da Geração Paissandu e os filmes da novíssima geração de cineastas brasileiros. Numa cultura cada vez mais massificada e midiatizada, ser jovem também significava negociar com um imaginário e a necessidade de forjar imagens novas em um universo de padrões e convenções.

Nos anos 1960, o Festival de Cinema Amador do Jornal do Brasil propiciou um espaço para o surgimento dessas imagens, sua fruição e o debate sobre elas. Presentes na sua segunda edição, os três filmes aqui analisados sintonizam a frequência de uma juventude que começava a pensar e produzir novos caminhos para a representação cinematográfica. Esses filmes errantes, de cineastas em formação, são importantes para a compreensão da trajetória posterior de seus cineastas e para a compreensão dos vínculos tecidos nos espaços de circulação de filmes, como o circuito de arte estabelecido no Rio de Janeiro dos anos 1960. O Jornal do Brasil foi ator e testemunha de todo esse movimento, um capítulo importante para a história do cinema brasileiro e para a cultura visual de sua época.

Conflitos de interesse: nada a declarar.

Fonte de financiamento: Coordenação de Aperfeiçoamento de Pessoal de Nível Superior (CAPES). 


\section{REFERÊNCIAS BIBLIOGRÁFICAS}

A VIDA PROVISÓRIA. Direção: Maurício Gomes Leite. Produção: J. P. de Carvalho. Intérpretes: Paulo José, José Lewgoy, Dina Sfat et al. Roteiro: Maurício Gomes Leite. Rio de Janeiro: Tekla Filmes; Saga Filmes; Luiz Carlos Barreto Produções Cinematográficas; J. P. de Carvalho Produção e Administração Cinematográfica Ltda., 1968, 88 min, son., BP, 35 mm.

ACOSSADO. Direção: Jean-Luc Godard. Produção: George de Beauregard. Intérpretes: Jean Seberg, Jean-Paul Belmondo et al. Roteiro: François Truffaut. Société Nouvelle de Cinématographie (SNC), Les Films Imperia, 1960, $87 \mathrm{~min}$, son., BP, $35 \mathrm{~mm}$.

ALENCAR, M. Nasce um cinema com o Festival JB. Jornal do Brasil, Rio de Janeiro, ano 75, n. 151, jun. 1966a, Caderno B, p. 5.

ALENCAR, M. As promessas do tédio e da coragem. Jornal do Brasil, Rio de Janeiro, ano 76, n. 126, jun. 1966b, Caderno B, p. 8.

ALENCAR, M. As vozes de São Paulo. Jornal do Brasil, Rio de Janeiro, ano 75, n. 125, maio 1966c, Caderno B, p. 8.

ALENCAR, M. O cinema em festivais e os caminhos do curta-metragem no Brasil. Rio de Janeiro: Editora Artenova e Embrafilme, 1978.

BAECQUE, A. Cinefilia. São Paulo: Cosac Naify, 2010.

BLÁ BLÁ BLÁ. Direção: Andrea Tonacci. Produção: Andrea Tonacci. Intérpretes: Paulo Gracindo, Irma Alvarez, Nelson Xavier et al. Roteiro: Andrea Tonacci. São Paulo: Total Filmes, 1968, 28 min, son., BP, 16 mm.

CANOSA, F. Pesquisa Festival de Cinema Amador - Geração Paissandu [mensagem pessoal]. Destinatário: lilafoster@gmail.com. [S. I.], 19 ago. 2020. Mensagem eletrônica.

CASTRO, R. Geração Paissandu: trinta anos essa noite. In: SEIXAS, H. (org.). Um filme é para sempre: 60 artigos sobre cinema. São Paulo: Companhia das Letras, 2006. p. 404-413.

CENTRAL DO BRASIL. Direção: Walter Salles Júnior. Produção: Martire de Clermont-Tonnerre e Arthur Cohn. Intérpretes: Fernanda Montenegro, Marilia Pera, Vinicius de Oliveira, Sônia Lira, Othon Bastos, Matheus Nachtergaele et al. Roteiro: Marcos Bernstein, João Emanuel Carneiro e Walter Salles Júnior. [S. I.]: Le Studio Canal; Riofilme; MACT Productions, 1998. 5 rolos de filme (106 min), son., color., 35 mm.

CLAMOR AO SEXO. Direção: Elia Kazan. Produção: William Inge, Charles H. Maguire. Intérpretes: Natalie Wood, Warren Beaty et al. Roteiro: William Inge. Newton Productions Inc., 1961, 124 min, son., color., 3 $5 \mathrm{~mm}$.

DURST, R. Geração Paissandu. Rio de Janeiro: Relume Dumará, 1996.

DOCUMENTÁRIO. Direção: Rogério Sganzerla. Produção: Rogério Sganzerla, Afonso Coaracy. Intérpretes: Vitor Lotufo, Marcelo Magalhães. Roteiro: Rogério Sganzerla. Produção Independente, 1966, 10 min, son., $B P, 16 \mathrm{~mm}$.

É TEMPO DE fazer cinema. Jornal do Brasil, Rio de Janeiro, ano 77, n. 127, 1967, 1 Caderno, p.1 9.

EDUARDO, C. Gente Jovem. Jornal do Brasil, Rio de Janeiro, ano 74, n. 14, jan. 1965, Caderno B, p. 3. 
EDUARDO, C. Gente Jovem. Jornal do Brasil, Rio de Janeiro, ano 75, n. 53, mar. 1966, Caderno B, p. 2.

ENNE, A. L. Juventude como espírito do tempo, faixa etária e estilo de vida: processos constitutivos de uma categoria-chave da modernidade. Comunicação, Mídia e Consumo, São Paulo, v. 7, n. 20, p. 13-35, 2010. http://dx.doi.org/10.18568/cmc.v7i20.203.

ESCRAVOS DE JÓ. Direção: Xavier de Oliveira. Produção: Denoy de Oliveira, Xavier de Oliveira. Intérpretes: sem informação. Roteiro: Xavier de Oliveira. Produção Independente, 1965, 13 min, son., BP, 16 mm.

FERREIRA, J. Cinema de invenção. São Paulo: Limiar, 2000.

FRANÇA, A.; PEREIRA, C. Super-heróis, intrépido, caretas: cultura jovem na publicidade e no documentário das marcas Shell e Esso nos anos 60 e 70. Significação: Revista de Cultura Audiovisual, São Paulo, v. 39, n. 38, p. 172-197, 2012. https://doi.org/10.11606/issn.2316-7114.sig.2012.71144.

HOBSBAWM, E. Era dos extremos: o breve século XX. 1914-1991. São Paulo: Companhia das Letras, 1995.

JORNAL DO BRASIL foi o primeiro da imprensa brasileira a publicar uma coluna dedicada exclusivamente ao cinema. Jornal do Brasil, Rio de Janeiro, ano 75, n. 110, maio 1966, $1^{\circ}$ Caderno, p. 9.

JUVENTUDE TRANSVIADA. Direção: Nicholas Ray. Produção: David Weisbart. Intérpretes: James Dean, Natalie Wood et al. Roteiro: Stewart Stern. Warner Bros., 1955. 111 min, son., color., $35 \mathrm{~mm}$.

LEITE, M. G. 0 cinema mais jovem. Jornal do Brasil, Rio de Janeiro, ano 76, n. 305, dez. 1966, Caderno B, p. 4.

LIMA, P. F. S. Caderno B do Jornal do Brasil: trajetória do segundo caderno na imprensa brasileira (1960-85). 2006. 267f. Tese (Doutorado) — Programa de Pós-Graduação em História Social, Universidade Federal do Rio de Janeiro, 2006.

MARIE, M. A Nouvelle Vague. Significação: Revista de Cultura Audiovisual, São Paulo, v. 30, n. 19, p. 165180, 2003. https://doi.org/10.11606/issn.2316-7114.sig.2003.65573.

MORIN, E. Cultura de massas no século XX. 0 espírito do tempo - 1. Neurose. Rio de Janeiro: Editora Forense Universitária, 1997.

O BANDIDO DA luz vermelha. Direção: Rogério Sganzerla. Produção: Julio Calasso. Intérpretes: Paulo Villaça, Helena Ignez, Luiz Linhares et al. Roteiro: Rogério Sganzerla. São Paulo: Distribuidora de Filmes Urânio Ltda., 1968, $92 \mathrm{~min}$, son., BP, $35 \mathrm{~mm}$.

O BEM-AVENTURADO. Direção: Neville D’Almeida. Produção: Neville D’Almeida. Intérpretes: Sérgio Lara, Helvécio Ferreira. Roteiro: Neville D'Almeida. Produção Independente, 1966, 13 min, son., BP, 16 mm.

O DESAFIO. Direção: Paulo César Saraceni. Produção: Mario Fiorani. Intérpretes: Joel Barcelos, Oduvaldo Viana Filho, Hugo Carvana et al. Roteiro: Paulo César Saraceni. Rio de Janeiro: Produções Cinematográficas Imago Ltda.; Mapa Filmes, 1964, 100 min, son., BP, 35 mm.

O PEDESTRE. Direção: Otoniel Santos Pereira. Produção: Otoniel Santos Pereira. Intérpretes: Otoniel Santos Pereira. Roteiro: Otoniel Santos Pereira. Produção Independente, 1966, 15 min, son., BP, 16 mm.

OS INCOMPREENDIDOS. Direção: François Truffaut. Produção: François Truffaut, Georges Charlot. Intérpretes: Jean-Pierre Léaud, Albert Rémy, Guy Decomble et al. Roteiro: François Truffaut, Marcelo Moussy. Les Films du Carrosse, Sédif Productions, 1959, 99 min, son., BP, $35 \mathrm{~mm}$. 
OLHO POR OLHO. Direção: Andrea Tonacci. Produção: Andrea Tonacci. Intérpretes: Daniele Gaudin, Francisco Arruda, Fabio Sigolo et al. Roteiro: Andrea Tonacci. Produção Independente, 1966, 22 min, son., BP, 16 mm.

ROCHA, G. Eztetyka da fome. In: PIERRE, S. Glauber Rocha: textos e entrevistas com Glauber Rocha. Campinas: Papirus, 1996. p. 124-130.

TERRA EM TRANSE. Direção: Glauber Rocha. Produção: Zelito Viana. Intérpretes: Jardel Filho, Glauce Rocha, José Lewgoy et al. Roteiro: Glauber Rocha. Rio de Janeiro: Mapa Produções Cinematográficas Ltda., 1967, 107 min, son., BP, $35 \mathrm{~mm}$.

VELOSO, G. Por uma arqueologia de um outro cinema. Contracampo: revista de cinema. [S.I.: s.n.], 1983. Disponível em: <http://www.contracampo.com.br/92/artoutrocinema.htm>. Acesso em: 7 ago. 2020. 